\title{
The New Russian Nationalism: Imperialism, Ethnicity and Authoritarianism 2000-2015
}

Edited by Pål Kolstø and Helge Blakkisrud. Edinburgh: Edinburgh University Press. 2016.

This useful and timely volume covers the growth of Russian nationalism from 2000 to 2015. It was in the process of completion during the annexation of Crimea in March 2014 and thus most of the chapters refer largely to events prior to that date, with some analytical coverage of how Russian nationalism has shaped public opinion of the annexation and subsequent Eastern Ukrainian conflict. It is thoroughly researched and yet accessible to the general reader, though with a few minor issues.

The collection aims to explore the different currents within contemporary Russian nationalism, analysing their complex relationship with the state and Russian society. It is an anthology, with different chapters, which offer contrasting and sometimes contradictory perspectives on the issue of Russian nationalism.

The book is divided into two main sections, with the first describing what Kolstø calls 'society-level' Russian nationalism, while the second is devoted to nationalism at state level and the changing discourse of Putin and the state in relationship to national identity. The final chapter is a discussion of nationalist economic policy in Russia and the debate at the state level between adopting protectionist policies or a more globalised economic model. This echoes current discussions in the West over pro-business policies such as privatisation, which have been blamed for creating a 'left-behind' class and fuelling sympathies for nationalist rhetoric, and underlines that Russia faces many of the same issues as Western countries in its approach to these issues.

As Kolstø states in the introduction to the book, there are several strands to Russian nationalism, ranging from traditional 'statist' nationalism, which values a strong state and an assertive foreign policy, to neo-Nazi groups, which promote an exclusionary version of the 'Russian people' based on ethnic purity, and the 'national-democratic' current including figures such as Navalny, who have in recent years sought to 'selfconsciously' model their movement on Western far-right populist movements.

The different types of Russian nationalism are often openly hostile to each other, such as ethnic Russian nationalists who favour a more culturally and racially pure state, and imperial Russian nationalists who are not openly hostile towards ethnic minorities, but favour territorial irredentism towards the borders of the former USSR and perhaps beyond. 
One possible weakness of the discussion of the contrast between the two in some chapters is that it is perhaps too generous to the imperialist Russian nationalists, as although ethnic minorities are tolerated in their vision for the country, their main emphasis has been on expanding the territory of Russia rather than promoting a multicultural society. Conversely, the fact that ethnic Russian nationalists are seen as unusual by supporting both irredentism and an ethnically Russian state misses the fact that this is a feature common to many nationalist movements.

An interesting chapter in the second half of the book concerns the relationship of the Russian Orthodox Church to Russian nationalism, and explores the tension between the hierarchy of the church and Orthodox nationalists who believe that it should take a stance more sympathetic to Russian 'ethnic pride'. While this chapter does at times gloss over some of the ways in which officials within the Russian Orthodox Church have promoted homophobia and anti-Semitism, and the participation of some priests in nationalist events, it is a more nuanced picture than what is usually found either in Western or in Russian media.

For example, it describes the tension between those parts of the Church (usually within the hierarchy) who wish to stay out of politics and occupy a more traditional religious role, and militant nationalists who are openly hostile to migrants and wish the church to take a stronger stance against other religions such as Islam, and how the decentralised structure of the church has enabled nationalists to gain positions within some parishes. However, despite the close relationship between the Russian state and the Orthodox Church it is not clear whether nationalists' relationship with the church should be described as 'state-level' nationalism, and this is not properly explained.

Other chapters explore the changing relationship between Putin and the state towards Russian nationalism. For example, in the post-2011 period, Putin increasingly referred to the Russian population in ethnic terms such as 'Russkie' rather than referring to 'citizens of Russia' as he had during the early part of his presidency. The book's contributors take differing stances on Putin's rhetoric, with some arguing that his turn towards ethnically-based language only took off after 2014 and the annexation of Crimea. The book shows that in the early 2010s, local authorities were often broadly supportive of anti-migrant campaigns by nationalist groups, those same groups were also seen as a potential threat to the authority of the state. Conversely, Russian nationalists are far from uniformly supporting Putin, particularly the radical far right, who see him as placing the interests of state elites ahead of ethnic Russians. 
76 REVIEWS: BOOKS

Many of the articles and studies in Kolstø's volume were written during or after the onset of the war in eastern Ukraine, and the book explores Russian attitudes to such issues as the Ukrainian conflict and migration as well as Russian media coverage of nationalist themes. Although some attitudes have remained fairly stable over time, such as the percentage of those agreeing with ethnocentric slogans such as 'Russia for the Russians', some findings suggest that a rise in ethnic Russian nationalism is overstated.

In places, especially towards the end, it can feel disjointed and some chapters seem repetitive. However, overall this book is very accessible (although some chapters do assume a level of knowledge of nationalist thought in Russia which some readers may not have) and essential reading for anyone studying this issue. It is largely unbiased, wellresearched and contains a range of often contrasting perspectives from differing authors, covering a broad range of topics relating to nationalism's impact on Russian society.

RACHAEL HORWITZ

School of Slavonic and East European Studies, University College London

This work is licensed under the Creative Commons Attribution-Non Commercial-Share Alike 4.0 International License. To view a copy of this license, visit bttp:// creativecommons.org/licenses/by-nc-sa/4.0/ or send a letter to Creative Commons, PO Box 1866, Mountain View, CA 94042, USA. 